\title{
KESULITAN BERBAHASA TOKOH ISHAAN \\ PADA FILM TAARE ZAMEEN PAR \\ (KAJIAN NEUROLINGUISTIK)
}

\author{
Givti Nova Damayanti \\ SMA Muhammadiyah 4 Surabaya \\ givtinovad37@gmail.com
}

\begin{abstract}
ABSTRAK
Film Taare Zameen Par berisi kisah seorang anak penyandang disleksia bawaan bernama Ishaan. Disleksia adalah salah satu kesulitan berbahasa. Pada Penelitian ini mencari tahu karakteristik disleksia yang dialami tokoh Ishaan pada film Taare Zameen Par beserta penyebab yang mendukung terjadinya kesulitan berbahasa tersebut hingga penanganannya, sesuai yang dilakukan dalam film tersebut. Penelitian ini menggunakan metode kualitatif. Deskripsi data dan transkrip dialog para tokoh sebagai sumber utama penelaahan pada penelitian ini. Kesulitan berbahasa pada tokoh Ishaan yang ditemukan adalah melingkupi kesulitan menulis dengan benar dan rapi sesuai ejaan, membaca sesuai ejaan yang benar dan jelas, memahami inStruksi, merespon tindakan dan stimulus tertentu dalam mengerjakan suatu hal yang biasa dilakukan anak seusianya, semua disebabkan karena terganggunya otak sebagai pusat koordinasi diri seseorang. Konektifitas saraf yang tak maksimal bahkan tak sesuai dengan lajurnya mengakibatkan disleksia terjadi, selain itu dasar utamanya adalah bentuk pisahan otak yang simetris menjadikan penyandang disleksia memiliki fisiologis otak yang tak normal seperti orang pada umumnya.
\end{abstract}

Kata kunci: taare zameen par, disleksia, neurolinguistik

\begin{abstract}
Taare Zameen Par is a film from India that contains the story of a child with dyslexia named Ishaan. Dyslexia is one of the language difficulties in neurolinguistics studies. This research find out about the types of dyslexia characteristics experienced by Ishaan characters in the TaareZameen Par movie and the causes that support the language difficulties to handle according to what is done in the film. This reseach used qualitative research methods. Description of the data and dialogue transcripts of the characters as the main source of review in this study is used. Language difficulties in Ishaan characters found were covering difficulties in writing correctly and neatly according to spelling, reading according to correct and clear spelling, understanding instructions, responding to certain actions and stimuli in doing things that are usually done by children in their own age, all are caused by disruption of the brain as a center of one's self-coordination. Nervous connectivity that is not optimal or not in accordance with the lane causes dyslexia to occur, besides the main basis of the form of symmetrical brain separation makes people with dyslexia have abnormal brain physiology like people in general.
\end{abstract}

Keywords: taraa zameen par, dyslexia, neurolinguistics 


\section{PENDAHULUAN}

Manusia hadir dan diciptakan oleh Tuhan Yang Maha Esa sudah mutlak dalam bentuk yang sebaik-baiknya. Setiap apa yang menjadi wujud kun fayakun Allah SWT memiliki maksud dan makna yang berbeda-beda. Tuhan tidak mungkin menciptakan segala apa yang ada di muka bumi ini tanpa manfaat, sekalipun manusia sebahagai bentuk khilafahnya. Setiap manusia dianugerahi oleh keistimewaan dan kekurangan masing-masing, manusia satu dan lainnya tentu berbeda. Selama ini kita masyarakat Indonesia terutama orang awam hanya melakukan penilaian sehari-hari terhadap apa yang menjadi wajar. Di luar keadaan wajar di pandang sebelah mata, tanpa memikirkan atau mempertimbangkan hal yang ada di dalamnya.

Penilaian terhadap suatu hal, salah satu contoh adalah pandangan masyarakat terhadap seseorang dengan kondisi tertentu yang merupakan kekurangannya, tapi Tanpa mengenal lebih jauh, tentu masyarakat awam sudah memberikan cap tertentu bagi mereka dengan berbagai macam gangguan atau kelainan tertentu. Setiap yang hidup tentu melakukan komunikasi baik verbal dan nonverbal. Masyarakat melakukan semua itu guna menciptakan kelangsungan hidup yang baik antarsesama dan dirinya sendiri. Dalam komunikasi, dibutuhkan bahasa sebagai pengantar. Bahasa duduk sebagai media penting dalam komunikasi. Komunikasi seorang manusia sudah ada sejak dalam manusia itu masih dikandung dalam rahim ibunya hingga tumbuh di dunia.

Bahasa terletak pada tingkatan tertinggi kebutuhan interaksi masyarakat. Bahasa mengantarkan pesan dan tujuan yang ingin dicapai penutur dengan mitra tutur. Pada kenyataan, kurangnya kesadaran masyarakat bahwa tidak semua manusia dapat mengemban bahasa dan memahaminya untuk diri sendiri dan melontarkan kepada mitra tutur dengan baik, sehingga pencapaian yang di inginkan tidak terwujud, ada beberapa kasus mengenai bahasa, mulai kelainan berbahasa manusia, gangguan dalam pembelajaran bahasa, pemerolehan bahasa dan lain sebagainya. Semua itu merupakan bidang kajian bahasa sebagai gejala pembentukan bahasa yang beragam.

Beragam kesulitan berbahasa atau gangguan dalam pemahamannya bisa saja terjadi pada setiap orang. Latar belakangnya juga tentu berbeda dalam setiap tubuh seseorang. Seseorang yang mengalami kesulitan memahami atau berbahasa dengan baik tentu akan kesulitan dalam kehidupan sosial dan perkembangan akademik 
sehari-harinya. Hal ini dapat mengancam masa depan seorang anak yang tumbuh dengan kesulitan berbahasa, terlebih jika orang tua tak menyadari keadaan anaknya tersebut.

Kesulitan berbahasa dapat berupa kesulitan membaca, pengenalan huruf, dan pemahaman mengenai komunikasi yang dilakukan. Keadaan ini akhirnya dapat merefleksikan dengan tepat kesulitan lain seperti kurang mampu mengenali perintah atau tidak bisa memperhitungkan keadaan diri dengan sekitar di beberapa kasus dan situasi tertentu.

Kesulitan seperti ini akan terjadi juga saat seorang anak menjalani proses belajarnya. Walaupun penyebabnya juga belum tentu hanya saat proses itu, karena bisa saja keadaan anak yang seperti itu terjadi karena penyebab bawaan atau lainnya, tetapi proses belajar berperan penting karena menentukan seorang anak mengetahui bahasa dan usaha dalam pemahaman bahasa ada proses tersebut.

Banyak faktor yang perlu disadari masyarakat dan diketahui oleh para orang tua, bahwa seorang anak yang mengalami kesulitan berbahasa belum tentu dikarenakan ia malas atau ia menyimpang, perlu di telisik lebih jauh lagi. Seorang anak justru perlu lebih diperhatikan dan bantu dalam mengenali kesulitannya ini. Penyebab dan jenis kesulitan perlu dikenali.

Penyebab keadaan anak bisa dari awal karena bawaan lahir, kejadian traumatik, atau cara belajar yang kurang tepat, karena setiap anak membutuhkan penanganan masing-masing dan tidak bisa disamaratakan dalam pemahaman dan perhatian yang dibutuhkan. Begitu pula dengan kesulitannya dalam berbahasa yang beragam, ada yang hanya sulit dalam membaca secara runtut, ada pula yang bahkan mengenali huruf saja tidak bisa sempurna, bahkan ada pula yang akhirnya berdampak pada aspek kehidupannya sehari-harinya yang lain, seperti tidak bisa memperhitungkan jarak, kurang memahami mengenai kemungkinan buruk yang ada di depan matanya dan lain sebagainya.

Gangguan berbahasa beragam bergantung pada jenis gangguan yang dialami oleh fisik atau kemampuan lain penderita, salah satunya adalah disleksia yang merupakan gangguan berbahasa yang dikarenakan oleh keadaan neurologi seseorang penderita disleksia yang berbeda dengan orang normal pada umumnya. disleksia hadir sebagai momok mengerikan bagi penderita jika keadaan ini diperparah dengan memojokkan 
penderita, dan tugas berat bagi para orang tua penderita jika ini dijadikan sebagai beban hidup yang serius, dan justru semua anggapan ini harus dibelokkan, karena setiap anak disleksia itu sebenarnya justru memilki kecerdasan tersembunyi yang tersirat yang bisa saja kurang dipahami oleh orang tua.

Penelitian ini menghadirkan kajian neurologik untuk mengenali dan meleburkan bahwa gangguan berbahasa anak yang disebut disleksia kemungkinan terbesar penyebabnya adalah karena kondisi otak penderita yang tidak sama dengan orang normal lain sehingga membuat ia mengalami keadaan yang tersebut. Dengan ini para orang tua dan masyarakat tidak melulu hanya menyalahkan anak saja yang justru sebagai korban, Ia tidak bisa memillih dilahirkan dengan anugerah fisik atau mental yang diterima.

Anak dengan disleksia tak akan menganggap kekurangan sebagai momok tapi justru sebagai bentuk penerimaan diri, dan orang tua yang awalnya menganggap beban justru sebagai wawasan dan pengalaman berbeda dan luar biasa serta sebagai upaya koreksi diri oarng tua terhadap anak. Anak dengan disleksia hadir di dunia tentu bukan tanapa alasan. Tuhan menganugerahi segala kelebihan padanya. Keadaaan fisik atau pengaruh lain bisa menjadi alasan munculnya disleksia pada diri anak, kita harus membantu mereka, karena mereka tidak bisa mengendalikan sendiri diri dan kelainannya tersebut.

Otak penderita disleksia tentu berbeda adanya dengan otak anak normal. Neuron pada otak yang berbeda dalam hal tentu menjadikan anak memilki kemungkinan disleksia dalam pengenalan huruf atau bahkan pemahaman bahasanya. Keberadaan otak sebagai pusat saraf segala tindak laku mengalami gangguan atau perbedaan bagi penderita disleksia. Disleksia sebenarnya bisa hadir pada diri anak dikarenakan dua hal yaitu bawaan lahir atau kecelakaan. Hal inilah yang harus dikenali para orang tua.

Penelitian ini menganalisis disleksia sebagai gangguan berbahasa dalam kajian neurolinguistik, yang merupakan perpaduan bidan kajian ilmu kesehatan mengenai neurologik dan kajian linguistik. Penelitian yang mengambil film menganai anak disleksia di negara India dalam judul Taree Zameen Par ini menganalisis Ishaan sebagai objek disleksia yang mengalami gangguan karena bawaan, kesulitan dan gangguan yang dia alami saya teliti untuk mencari ruang lingkupnya mulai dari 
penyebab, bentuk gangguan, sampai pengenalan disleksia yang terjadi pada dirinya yang kemudian di kaji dalam ilmu kebahasaan otak.

Tujuan penelitian pada penelitian ini yang pertama adalah mendeskripsikan kategori disleksia dan penyebabnya pada tokoh Ishaan dalam film Taare Zameen Par sebagai salah satu bentuk kesulitan berbahasa sesuai kajian neurolinguistik. Kedua, mengetahui cara penanganan disleksia yang dialami tokoh Ishaan pada film Taare Zameen Par. Penelitian ini memberikan manfaat antara lain bagi penulis adalah mempertajam pengetahuan mengenai korelasi keilmuan bahasa dengan kesehatan dan memberikan pelajaran tentang kepekaan terhadap wawasan mengenai kondisi, potensi, dan penanganan penyandang disleksia.

Bagi masyarakat adalah, memberikan pengetahuan dan wawasan tambahan mengenai keberadaan anak-anak dengan disleksia, agar masyarakat dapat memilki kepekaan dan sikap adil terhadap keberadaan mereka, bisa membantu proses penanganan, dan menyadari potensi kecerdasan yang dimiliki, dan bagi ilmu pengetahuan untuk menambah khazanah keilmuan tentang kajian psikolinguistik, dengan aspek khususnya yakni pada kajian neurologi bahasa, sehingga dapat menambahkan informasi tambahan yang mempertebal keberadaan wawasan mengenai neurologi bahasa.

\section{METODE PENELITIAN}

Jenis penelitian menggunakan penelitian kualitatif yang mendeskripsikan berupa penjelasan secara sistematis baik dari permasalahan, analisis hingga hasil akhir penelitian yang disajikan dalam bentuk deskripsi susunan kalimat-kalimat yang dibentuk hingga mencapai sebuah narasi penjelasan untuk pembaca. Desain penelitian pada skripsi ini menggunakan desain penelitian deskriptif. 


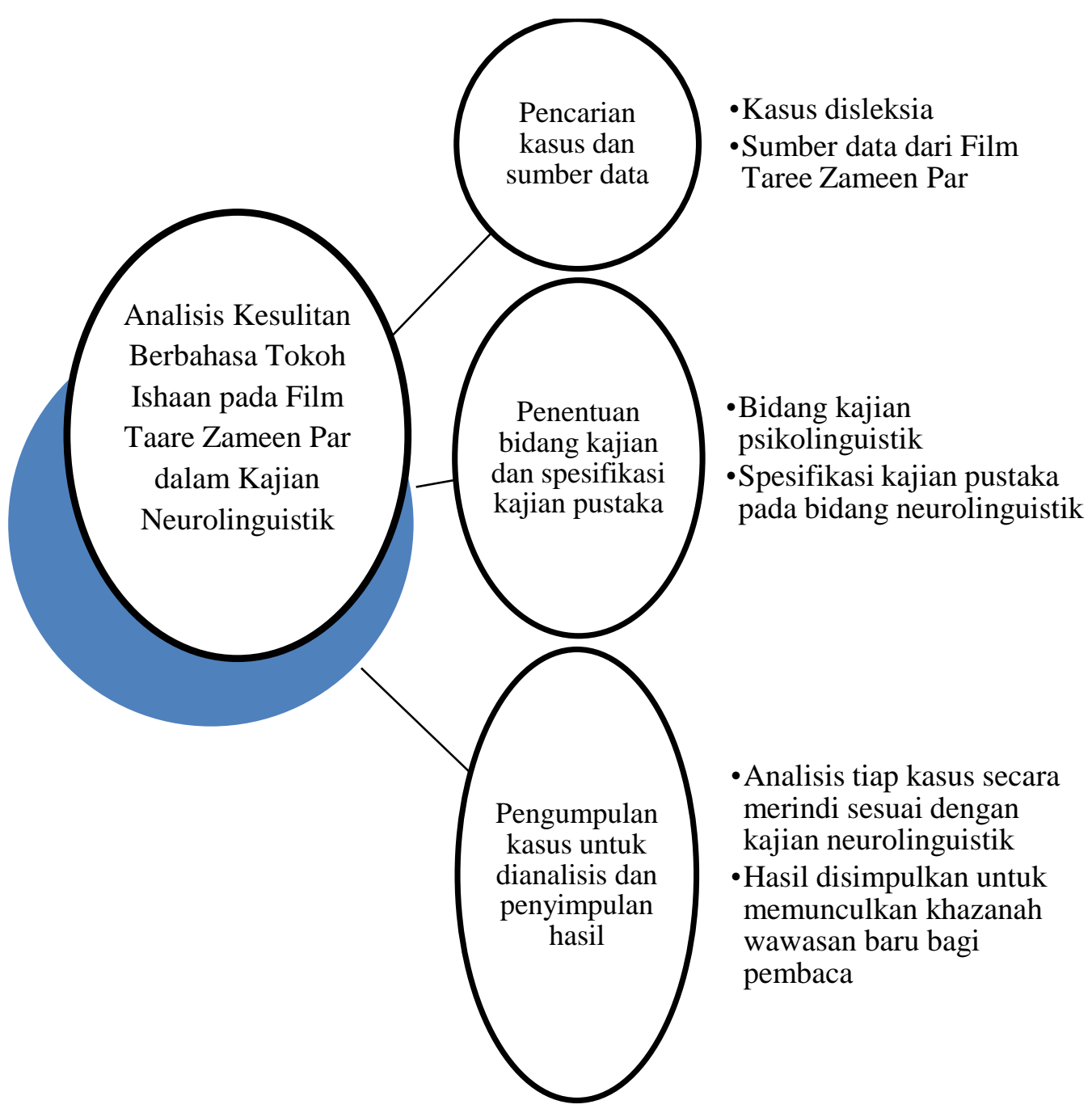

Skema desain penelitian

Sumber data/objek penelitian berasal dari film Taare Zameen Par (Seperti Bintang-Bintang di Langit). Sumber data atau objek yang digunakan pada penelitian ini berasal dari film yang berasal dari negara India berjudul Taare Zameen Par. Selain film, peneliti membutuhkan sumber data yang berasal dari buku kajian neurologik dan linguistik serta referensi biografi pemeran.

Teknik pengumpulan data dan bahan-bahan yang dibutuhkan untuk penyusunan skripsi ini dengan cara studi dokumen. Studi dokumentasi yang merupakan metode pengumpulan data yang tidak ditujukan langsung kepada subjek penelitian. Studi dokumen adalah jenis pengumpulan data yang meneliti berbagai macam dokumen yang berguna untuk bahan analisis. 
Teknik analisis data dilakukan berdasarkan pengamatan pada sumber data dan objek penelitian. Pada penelitian ini menggunakan teknik analisis sebagai berikut:

1. Menentukan materi yang akan dianalisis

2. Mentranskrip materi berupa film, dari bentuk lisan dialog menjadi tulisan dari percakapan para tokoh

3. Mengelompokkan data berdasarkan klasifikasi yang sudah ditentukan

4. Menganalisis data berdasarkan kajian disleksia

5. Menyimpulkan hasil analisis

\section{PEMBAHASAN}

Penelitian ini diambil dari film India berjudul Taare Zameen Par. Film ini menceritakan seorang anak asal India yang masih duduk di bangku sekolah dasar, ia mengalami disleksia, sehingga ia tak bisa berbahasa dengan baik dan sesuai dengan umurnya. Hal ini juga menghambat proses berkomunikasi, prestasi dan krisis kepercayaan dirinya. Tekanan keluarga mengharuskan ia menjadi anak yang berprestasi tanpa menghiraukan masalah yang sedang dihadapi, Akhirnya ia bertemu guru seninya yang memiliki simpati untuk membantu mengentaskannya dalam keterpurukan, dan mengubahnya menjadi anak yang sama dengan anak lainnya bahkan jauh lebih hebat. Penanganan tertentu dilakukan untuk mengatasi diseleksia yang ia alami dengan mengenali lebih dulu karakter disleksia dan penyebabnya.

Ishaan adalah anak kelas tiga sekolah dasar, dua bersaudara dari pasangan Nandkishore Awasthi dan Maya Awasthi. Ayahnya seorang pengusaha terbiasa hidup teratur bahkan cenderung dalam tekanan yang keras saat melewati keseharian menjadikan ia membentuk anak-anaknya menjadi anak yang harus sesuai dengan garis apa yang diinginkan dirinya. Sebuah pencapaian cemerlang, sebuah nama baik, keunggulan sangat dijunjung tinggi oleh ayah Ishaan. Ibunya seorang ibu rumah tangga yang sangat baik dalam mengurus rumah dan anak serta suaminya, menjadi orang yang menganut suaminya, tak terlalu berani menentang, karena merasa kodratnya sebagai istri dan adat serta kebiasaan prinsip masyarakat India yang sangat mendewakan seorang suami, membuat Maya Awasthi tak begitu berani mengungkapkan isi hati dan ketakutannya mengenai kelemahan anaknya pada 
suaminya yang terlanjur menganggap Ishaan anak yang bodoh dan nakal, terlebih saat membandingkan dengan putra pertamanya yang berbanding terbalik dengan Ishaan.

Keadaan ini menjadikan Ishaan merasa dalam tekanan dan membuat krisis kepercayaan dirinya sendiri. Orang tuanya tak memahami betul apa masalahnya karena mereka tak tahu apa yang sedang dialami Ishaan sebenarnya. Tuntutan demi tuntutan didapatkan Ishaan. Tuduhan mengenai semua hal negatif yang ditujukan padanya. Pandai melukis, menyimpan kecemerlangan di dalam dirinya tak membuat orang tuanya sadar. Ishaan dikirim jauh menempuh pendidikan lebih keras lagi karena ego ayahnya untuk harus mengenyam pendidikan secara lebih ketat dan menekan lagi. Asrama tak menjadikan Ishaan membaik, justru lingkungan barunya merenggut sebagian dari hidupnya. Dia tak lagi melukis, tak lagi ceria, merasa semakin tak diinginkan oleh orang tuanya. Ishaan semakin jatuh dan tak berdaya, semakin mengalami kemunduran dan keadaan yang mengkhawatirkan. Akhirnya datang guru seni yang justru mempercayaai keajaibannya, membantu kelemahan dan kekurangannya hingga sembuh, Ishaan menjadi anak yang akhirnya dipandang dan diperhitungkan. Ishaan menjadi siswa yang memiliki penilaian akademik dan seni yang cukup memuaskan. Perkembangan yang signifikan dan ke khasan pada diri Ishaan membuat semua orang di sekitarnya sadar bahwa selama ini ia tak bodoh atau mengingkari aturan. Ia hanya butuh pengenalan, pendekatan dan penanganan yang tepat.

Tokoh Ishaan mengalami permasalahan gangguan berbahasa berupa disleksia. Disleksia yang dialami Ishaan pada film ini termasuk dalam disleksia bawaan, keadaan disleksia di dapatkan oleh Ishaan secara genetis. Faktor genetis Ishaan disebabkan oleh keturunan alias mewarisi struktur dan fungsi otak yang tidak normal akibat kesehatan rahim atau ibu penderita yang kurang baik. Hal ini dijelaskan karena sesuai dengan keadaan asli penderita yang diperankan Ishaan dalam film. Saat dilakukan pemerikasaan lebih lanjut mengenai permasalahan ini diperoleh bahwa hasilnya memang dari keadaan rahim ibu yang kurang sehat, sehingga menghasilkan disleksia turunan, bukan disleksia karena trauma tertentu, seperti kecelakaan atau benturan tertentu. Disleksia yang dialami Ishaan menunjukkan beberapa tanda ketidaktepatan pemahaman berbahasa. Beberapa kasus di dalam film menunjukkan bahwa tokoh Ishaan mengalami diskleksia sebagai salah satu gangguan berbahasa. 
Pada kasus pertama, saat itu Ishaan melamun melihat di luar jendela sekolah dan kurang memperhatikan guru bahasanya saat memerintahkan untuk membuka buku dan membahas mengenai kata sifat, sedangkan Ishaan tak sedang memperhatikan guru tersebut. Guru tersebut marah dan menegur Ishaan dan mengulangi perintahnya untuk membuka buku dan membaca kalimat yang ada di dalamnya dan menyebutkan kata sifatnya. Ishaan sama sekali tidak bisa menangkap dengan baik perintah dilontarkan gurunya terkait perintah yang berurutan seperti ini "Buka halaman 38, bab 4, paragraf 3!".

Pada saat dialog itu diucapkan oleh guru Ishaan, ia menunjukkan respon berupa kebingungan dan menoleh ke arah teman teman yang ada disekitarnya karena merasa tidak memahami apa yang di katakan gurunya. Ishaan bukan berarti tak mengindahkan perintah gurunya, tapi ia tak bisa menguraikan apa yang dimaksudkan gurunya secara jelas. Ishaan tidak bisa memahami urutan intruksi yang diucapkan gurunya secara cepat. Keadaan ini semakin dikuatkan ketika gurunya mengatakan "Halaman 38, Ishaan. Adit Lamba bantu dia.". Pada saat itu Adit Lamba, teman sebangku Ishaan membukakan halaman yang dimaksudkan guru untuk Ishaan. Ini memperlihatkan bahwa memang sebelumnya Ishan bahkan tak mengetahui bagian mana yang harus dibaca. Tapi setelah dibukakan halaman yang dimaksud Ishaan juga belum lagi memahami kewajiban dia berikutnya setelah mengetahui halamannya, yaitu membaca tulisan yang ada di halaman tersebut. Kesulitan Ishaan tersebut diakibatkan fungsi serebral Ishaan pada Korpus kolosum yang menghubungkan kedua hemisfer otak dan bertanggung jawab dalam transmisi informasi dari salah satu sisi otak ke bagian lain tidak bekerja dengan baik,saraf yang bekerja tidak terkoneksi dengan baik mengakibatkan status intelektual Ishaan ikut terpengaruh terlihat dari ia tidak memahami apa yang telah diperintahkan guru tersebut karena penyampaian materi dari hemisfer otak tidak terhubung dengan baik sehingga transmisi informasi tidak selesai dengan tuntas saat sampai ke otak.

Ishaan mengalami disleksia diseidesia yang bisa dikategorikan tidak bisa mengenali daftar instruksi secara baik, Ia tak mudah untuk berkonsentrasi terhadap perintah yang di sebutkan guru dan seolah sulit menemukan titik fokus dalam dirinya. Kelanjutan dari dialog pada kasus pertama, Ishaan mengalami distorsi shaky pada tulisan di buku yang ia baca. Ini diidentifikasi dari jawaban Ishaan. Ketika didesak 
gurunya untuk membaca, ia justru menjawab dengan jawaban "Mereka menari”. Jawaban Ishaan bermaksud bahwa huruf yang dilihat oleh matanya sedang melakukan gerakan dalam kata mudah untuk anak seusianya huruf yang dibaca sedang menari. Distorsi shaky yang dialami Ishaan berupa penglihatan mata Ishaan terhadap tulisan yang berubah menjadi huruf tampak bergerak menari-nari di tempat, bergoyang goyang ke kiri dan ke kanan. Bahkan dalam beberapa kasus menari hingga keluar kertas. Hal ini terlihat dari jawaban Ishaan saat dipaksa gurunya untuk membaca tulisan pada buku. Ia mengatakan bahwa tulisannya menari. Jawaban tersebut bukan karena Ishaan sedang melucu atau melawan apa yang dikatakan gurunya tapi ini akibat oksipital yang terletak pada lobus posteriorhemisfer serebri bermasalah. Keadaan sel saraf oksipital tidak bekerja dengan baik pada lobus sehingga mengakibatkan penglihatan Ishaan pada tulisan di media cetak menjadi dalam kategori jenis distorsi shaky.

Pada kasus ketiga, Ishaan mencampur huruf yang mirip pada tulisan, dan mengganti pengucapan yang mirip pada tulisan sesuai dengan perspektif dirinya sendiri pada otaknya. Terlihat dari dialog berikut yang diucapkan Maya Awasthi (Ibu Ishaan) “Table ditulis Tabl, kemudian Tabel, dan “d”, bukannya "the" ?". Maya Awasthi mengatakan hal yang ia baca dari hasil pekerjaan Ishaan di dalam buku tulisnya. Mereka sudah melakukannya beberapa kali sebagai latihan Ishaan dalam mengeja. Namun Ishaan tetap mengulang kesalahannya dengan tipe kesalahan yang sama. Kejanggalan ini kurang disadari oleh ibu Ishaan bahwa anaknya melakukan pengulangan kesalahan di tipe yang sama, bukan karena malas atau tak cerdas. Hal ini terjadi hampir sama pada kasus pertama yaitu karena fungsi serebral yang terletak pada korpus kolosum tidak bekerja dengan baik, sehingga transfer informasi pada hemisfer juga tak terlaksana secara tuntas. Disleksia yang dialami Ishaan seperti ini dapat dikategorikan sebagai disleksia dismenkinesia developmental, daya ingat dan pergerakan motorik yang menyebabkan si penderita cenderung membolak-balikkan huruf di dalam kalimat. Selain itu penderita disleksia jenis ini kerap mengalami kesulitan membuat kata dan membangun kosakata.

Pada kasus keempat, Ishaan mengalami masalah saat guru bahasa Inggrisnya menyampaikan mengenai penjelasan materi pelajarannya berkaitan dengan penjelasan grammar yang sama sekali tidak bisa dipahami Ishaan untuk memulai awal 
pemahaman hingga selesainya penahaman. Fungsi serebral yang bermasalah hampir sama seperti pada kasus pertama sehingga mempengaruhi status intelektual. Pada kasus ini disleksia yang dialami Ishaan terletak pada kategori ingatan jangka pendek yang dia alami, menjadikan ia mudah lupa terhadap apa yang sudah disampaikan sekalipun hanya berjarak beberapa menit atau bahkan detik.

Pada kasus kelima, kategori disleksia yang mencampur huruf yang mirip pada tulisan. Disleksia dismenkinesia developmental akibat dari fungsi serebral yang terletak pada korpus kolosum yang bermasalah, hampir sama seperti kasus ketiga. Hanya saja ini lebih dalam lagi kesulitannya karena Ishaan juga tidak bisa membedakan pencerminan kata yang dia bolak balik dan mengganti satu huruf dengan huruf lain yang memiliki persamaan menurut persepsi dirinya sendiri.

Pada kasus keenam, Ishaan ternyata juga tidak bisa melakukan hal umum yang biasa dilakukan anak seusianya. Nikumbh mengungkapnya saat ia bertanya kepada orang tua Ishaan seperti ini, "Apakah Ishaan kesulitan mengancingkan kancing bajunya atau mengikat tali sepatu?" (bertanya pada ibu Ishaan). Maya Awasthi menjawab (Ibu Ishaan) "Ya"

Dari dialog di atas terlihat bahwa Ishaan selama ini kesulitan melakukan hal-hal yang wajar dilakukan anak seusianya, karena kesulitan dalam berkonsentrasi. Ishaan tidak dapat menggunakan pakaian dengan baik karena ketepatan dan daya kemampuannya yang rendah dalam menggerakkan ketepatan jarinya untuk meletakkan pada apa yang seharusnya karena saraf otak yang juga tak tepat pada bagiannya. Pada sel saraf halusnya di dalam serebri tak melakukan sebaik seperti pada manusia normal, sehingga ia tak begitu bisa merangsang ke otaknya sehingga ia tak mampu untuk sekedar mengancingkan baju.

Pada kasus ketujuh, Ishaan tidak dapat memperhitungkan tentang jarak, kecepatan saat bermain bola, sehingga ia tak pernah bermain bola. Dia melempar itu tak sesuai pada tujuan yang diinginkan. Ini juga diungkapan Nikumbh. Ia menebak hal yang tepat sesuai dengan karakteristik yang biasa dialami penderita disleksia. Jadi yang ia ungkapkan tepat dengan keadaan Ishaaan yang sebenarnya, Ishaan menduduki disleksia tingkat sedang yang masih bisa dikenali dan menyandang kelemahan-kelemahan umumnya penyandang disleksia. Hal tersebut terlihat pada dialog berikut ini. 
"Jika anda melempar bola dapatkan dia menangkapnya?" (Nikumbh berganti bertanya pada Johan)

"Dia tidak pernah bermain bola" (sahut Johan)

"Karena dia tidak dapat menghubungkan ukuran, jarak dan kecepatan bola ukuran berapa, dari jarak berapa, menggelinding dengan kecepatan seberapa dan ketika dia menyadari jarak dan kecepatan bolanya, itu sudah terlambat. Coba pikirkan seorang anak sekitar umur 8 sampai 9 tahun tidak dapat membaca dan menulis, tidak dapat melakukan hal-hal yang sudah umum. Gagal melakukan segala sesuatu yang dilakukan anak seusianya, seperti tidak ada usaha" (berusaha memberikan informasi).

Sesuai dialog yang di atas, disleksia merupakan kategori ingatan jangka pendek, kelemahan penderita dalam memperhitungkan jarak dan kecepatan, diakibatkan integrasi motor kortikal pada kemampuan motorik yang bermasalah bisa mengakibatkan ini dan munculnya kategori disleksia ini.

Nikumbh memulai usaha penyembuhan pada Ishaan dengan mendekati dahulu, mengenalkan Ishaan pada orang-orang hebat yang ternyata menyandang disleksia sama seperti dia. Nikumbh secara tidak langsung menerapkan cara penanganan Remidial teaching, untuk menangani kasus ini dalam tahapan pendekatan pada peningkatan motivasi Ishaan dan melakukan pendekatan pada orientasi pemahaman dan pengetahuan dasar anak dilakukan oleh Nikumbh pada awal proses in. Hal ini bertujuan untuk menerka usaha dan cara apa yang pas untuk Ishaan bisa menangkap pelatihan dengan baik dan memberikan dampak yang positif bagi perkembangan belajarnya.

Nikumbh melakukan ini untuk mencuri rasa percaya Ishaan kepada dirinya bahwa ia bisa membantunya. Nikumbh cukup baik dalam membaca peluang untuk membantu Ishaan dengan cara-cara pendekatan sederhana dan bekerja secara terencana, pembangunan tugas yang terencana dan teranalisis terlihat dilakukan oleh Nikumbh dalam usahanya menggunakan metode Remidial Teaching. Pada kasus ini yang bermasalah adalah keadaan otak yang menjadi bawaan Ishaan sebagai penderita disleksia. Nikumbh memulai dengan merangsang daya peka saraf halus Ishaan. Cara sederhana dengan menyuruh Ishaan melukis huruf di atas pasir. Hal ini merangsang motorik Ishaan. Saraf pada serebri Ishaan yang awalnya kurang kuat dalam menangkap respon menjadi terlatih untuk merespon dengan tepat mengenai apa yang 
dirasakan Ishaan. Cara ini membuat Ishaan mengalami sendiri apa yang harus ia kerjakan dan otaknya terlatih untuk melakukan usaha dalam membentuk apa yang diinginkan Ishaan.

Nikumbh membuat media yang paling sederhana untuk lebih mudah ditangkap oleh saraf Ishaan. Sentuhan pasir di jari Ishan akan merangsang saraf haluasnya. Usaha tersebut dilanjutkan Nikumbh dengan memberikan penguatan rangsangan untuk kepekaan Ishaan lebih dalam lagi dengan menyentuhkan jarinya pada lengan Ishaan untuk membentuk sebuah huruf yang kemudian ditebak Ishaan dengan mata tertutup. Kegiatan ini bercermin pada tahapan Remidial Teaching dalam dukungan perangkat teknik yang disapkan untuk disesuaikan dengan kebutuhan anak.

Otak Ishaan semakin terlatih dengan latihan ini. InStruksi yang pasti dilakukan Nikumbh untuk mencapai ketepatan tujuannya dalam kegiatan usaha penyembuhan untuk Ishaan. Dengan ini, korpus Ishaan yang awalnya tidak bekerja maksimal mulai dirangsang secara langsung, Ishaan meraba yang ia rasakan dan ditransfer dalam otaknya untuk dirangkai dalam sebuah tebakan huruf yang tepat. Latihan ini juga berlaku pada saat Ishaan membuat huruf dari plastisin. Selain untuk membuat suasana senyaman mungkin dalam terapi ini, Nikumbh mencari media terbaik yang paling mudah bisa diserap oleh saraf Ishaan. Bentuk tiga dimensi sangat merangsang lobus serebrum Ishaan dan Oksipitalisnya sehingga penglihatan yang dia terima masuk ke otak dengan baik, dan tentunya ini dilakukan dengan intensif dan terus menerus dengan suasanya paling santai dan menyenangkan.

Setelah itu, Nikumbh melatih ketepatan Ishan dalam berkonsentrasi dan mengenal jarak dengan menyuruh Ishaan membentuk angka 8 pada kotak yang disiapkan dengan bentuk kotak yang semakin lama semakin berbentuk lebih sempit. Pada pelatihan ini berguna agar integrasi motor kortikal pada kemampuan motorik Ishaan membaik, dan melatih ketepatan konsentrasi Ishaan. Latihan ini selain untuk daya ketepatan Ishaan akhirnya juga berpengaruh pada pemusatan pandangan yang juga berhubungan dengan konsentrasi Ishaan saat melihat tulisan yang terbaca olehnya seperti menari. Kemudian Ishaan mulai mengeja kata yang ditulis Nikumbh dengan tepat dengan cara Ishaan berlatih mengeja dengan menirukan suara rekaman sambil matanya dilatih membaca menggunakan alat yang sudah disiapkan Nikumbh. Pelatihan ini untuk meminimalkan disleksia dismenkinesia developmental akibat dari 
fungsi serebral yang terletak pada korpus kolosum yang bermasalah yang dialami Ishaan.

Ishaan mulai semakin menunjukkan perkembangan dengan ia sudah bisa mengeja dengan baik dan benar, membaca dengan kuantitas waktu yang tepat, bentuk tulisan yang semakin membaik. Bahkan, dia bisa menulis dengan baik dan benar setiap huruf bahkan kata yang diejakan atau diperintahkan.

\section{PENUTUP}

Disleksia yang dialami Ishaan merupakan disleksia bawaan dari lahir. Keadaan otak penderita tidak sama dengan manusia normal. Belahan otak penderita disleksia cenderung simetris sehingga imbang di kedua belahannya, yang mengakibatkan bentuk saraf dan lajur sel tak sama seperti manusia normal. Keadaan ini yang menjadikan beberapa keadaan menjadi berbeda antara penderita disleksia dengan manusia normal.

Disleksia bawaan Ishaan pada penelitian ini ditemukan kategori disleksia kombinasi antara dismenkinesia dan diseidesia. Keduanya hampir memiliki kesamaan untuk saling berkesinambungan dalam kelemahan yang dialami Ishaan. Beberapa kategori disleksia yang dialami Ishaan sesuai dengan temuan kasus adalah buruknya kemampuan pengenalan daftar instruksi karena kelemahan fungsi serebral dalam korpus kolosum yang bermasalah mengakibatkan status intelektual terganggu. Kedua distorsi shaky saat ia membaca tulisan, akibat oksipital yang terletak pada lobus posteriorhemisfer serebri bermasalah. Pada kasus berikutnya kategori disleksia yang mencampur huruf yang mirip pada tulisan, disleksia dismenkinesia developmental. Keempat disleksia ingatan jangka pendek yang berpengaruh pada status intelektual karena serebri bermasalah, kelima kategori disleksia yang mencampur huruf yang mirip pada tulisan, disleksia dismenkinesia developmental dan keenam sulit berkonssentrasi karena fungsi serebral yang terletak pada korpus kolosum yang bermasalah. Terakhir permasalahan memperhitungkan jarak yang mengarah pada disleksia jangka pendek karena integrasi motor kortikal pada kemapuan motorik yang tidak sesuai.

Pada penelitian ini juga ditemukan penanganan untuk kondisi disleksia Ishaan. Dari perangsangan saraf halus Ishaan untuk mengembalikan dengan baik fungsi 
serebri pada korpus dan lobus Ishaan, Nikumb melakukan pelatihan konsentrasi dan pemusatan ketepatan untuk kemampuan daya ingatan jangan pendek Ishaan dan penebalan konsentrasi Ishaan serta pengembaliaan krisis diri Ishaan dengan cara merangkul dia dan membuat dia merasa dibutuhkan dan kehadirannya dihargai.

\section{DAFTAR RUJUKAN}

Ahmadi, Anas \& Jauhar. 2015. Dasar-Dasar Psikolinguistik. Jakarta : Prestasi Pustakaraya.

Boby, Olivia \& Vica. 2016. Disleksia (Bukan Bodoh, Buka Malas, tetapi Berbakat!). Jakarta : PT. Gramedia Pustaka Utama.

Brenda \& Suzanne. 1997. Buku Ajar Keperawatan Medikal Bedah . Jakarta: Penerbit Buku Kedokteran EGC.

Pearce, Evelyn. 2013. Anatomi dan Fisiologi untuk Paramedis. Jakarta : PT. Gramedia Pustaka Utama.

Petalagi. 2017. 10 Fakta Unik tentang Film Taare Zameen Par (2007). Diakses dari : http://www.petelagi.com/10-fakta-unik-tentang-film-taare-zameen-par-2007/. Mei, 1, 2018.

Wikipedia. 2018. Disleksia. Diakses dari : https://id.wikipedia.org/wiki/Disleksia. Mei, 1, 2018. 